\title{
PRODUCTIVITY IMPROVEMENT THROUGH THE IMPLEMENTATION OF LEAN MANUFACTURING IN A MEDIUM-SIZED FURNITURE INDUSTRY: A CASE STUDY
}

\author{
A.L. Gazoli de Oliveira ${ }^{1 *} \&$ W.R. da Rocha Junior ${ }^{2}$
}

\section{ARTICLE INFO}

\section{Article details}

Submitted by authors 4 Jan 2019

Accepted for publication 16 Aug 2019

Available online $12 \mathrm{Dec} 2019$

\section{Contact details}

* Corresponding author andre.gazoli@ufpr.br

Author affiliations

1 Industrial and Systems Engineering, Pontifical Catholic University of Parana, Curitiba, Brazil \& Industrial Engineering, Federal University of Parana, Jandaia do Sul, Brazil

2 Instituto SENAI de Tecnologia em Madeira e Mobiliário, Arapongas, Brazil

\section{DOI}

http://dx.doi.org/10.7166/30-4-2112

\section{ABSTRACT}

Small and medium-sized enterprises (SMEs) are very important to national economies. In Brazil, the furniture sector has many SMEs that suffer from international competition, especially from Chinese companies. To reduce this difficulty, this study provides a case study of the partial implementation of lean manufacturing (LM) in a medium-sized furniture industry with the aim of increasing productivity. As a result, the company increased its productivity by 27 per cent in the drilling sector. In addition, the case study shows how to implement $L M$ in a medium-sized furniture industry, demonstrating the need to adapt the system to companies outside the automobile sector.

\section{OPSOMMING}

Klein- en mediumgrootte ondernemings is baie belangrik vir nasionale ekonomieë. In Brasilië bevat die meubelbedryf vele kleinen mediumgrootte maatskappye wat swaar kry as gevolg van internasionale mededinging, veral van Sjinese ondernemings. Om hierdie uitdaging te oorkom bied dié artikel 'n gevallestudie van die gedeeltelike implementering van lenige vervaardiging in ' $\mathrm{n}$ mediumgrootte meubelmaatskappy met die doelstelling om produktiwiteit te verhoog. Die maatskappy se produktiwiteit is verhoog met 27 per sent in die boorsektor. Verder toon die gevallestudie hoe om lenige vervaardiging te implementeer in ' $\mathrm{n}$ mediumgrootte meubelmaatskappy. Sodoende word die behoefte om hierdie konsep aan te wend in ondernemings buite die tradisionele motorvervaardiging-sektor geïllustreer.

Lean manufacturing (LM) emerged from the International Motor Vehicle Program (IMVP) research project developed by the Massachusetts Institute of Technology. At the end of the IMVP, the book The machine that changed the world [1] was published and disseminated by the term lean production [2] worldwide. LM has evolved since its inception, and is currently used in manufacturing, services, and research and development, and is being adopted by the public and private sectors [3]. Modig and Åhlström [3] identified 17 different definitions based on the concept's level of abstraction. Given this wide diversity of definitions, in this study we adopt the approaches presented by Pettersen [4]: toolbox lean, leanness, becoming lean, and lean thinking. In these four different approaches, Pettersen [4] established that LM has a philosophical (ostensive) focus by approaching a general philosophy defined only by examples and a practical (performative) focus when emphasising the execution of activities. The existence of two strands is also emphasised: operational (discrete), which is directed to the specific improvement of isolated events, characterised by toolbox lean and leanness; and strategic (continuous), which is process-oriented (improvement of production flow), characterised as becoming lean and lean thinking.

LM has also been studied in the small and medium-sized enterprise (SME) environment. Several authors have conducted research on LM in SMEs, such as critical success factors (CSFs) $[5,7,8]$; 
enablers and inhibitors [6, 10]; frameworks, road maps, and methodologies [11-17]; and LM implementation in SMEs $[9,18,19]$.

SMEs are very important for national economies. Gonzales Hommes and Mirmulstein [20] emphasised the importance of these companies by presenting global numbers: 28.7 million formal SMEs employing approximately 325.5 million people. However, these SMEs generally have disadvantages in relation to large companies, such as difficulty in obtaining economies of scale through volume production or volume purchasing of raw materials. The fact that many SMEs do not have a vision of waste reduction is also unfavourable, as they are thus more vulnerable to economic fluctuations and financial losses, and so must prioritise investments. In this scenario, LM contributes to resolving and improving several problems faced by SMEs [5], rationalising internal production and allowing the company to adapt to external changes and the needs of the global market [15], as well as providing these companies a new competitive advantage [22].

According to a report from the Brazilian Development Bank (BNDES) [23], the furniture industry in Brazil has low competitiveness, mainly in the international market, because of a lack of productivity gains, poor innovative performance, low qualifications, and technological backwardness. These factors negatively impact the companies in this sector, especially with the increasing penetration of China into the Brazilian economy. In this scenario, some institutions linked to the furniture sector have developed LM implementation initiatives.

There is a lack of research on LM to improve productivity in the furniture sector. Few documents reporting initiatives to implement LM techniques, tools, or practices in the furniture industry in Brazil have been identified [24-29]. This fact motivated the development of this study. This article presents a case study on LM implementation in a medium-sized enterprise in the Brazilian Southern Furniture Sector. We used a specific framework, called the lean furniture framework (LFF), to conduct the case study. The LFF was developed by the authors, from a systematic literature review and semi-structured interviews with experts, to attend to the needs of the small and medium enterprises (SMEs) of the Brazilian furniture sector. In this article we use the LFF as a way to increase productivity through implementing the LM; thus we do not detail the development of the LFF.

The remainder of the article is arranged as follows. The next section presents the research methodology and the details of the LFF. Section 3 presents the case study conducted in a mediumsized enterprise. Section 4 presents the lessons learned and implications for production. Finally, section 5 presents the conclusion.

\section{RESEARCH METHODOLOGY}

We employed a case study as the research strategy. Yin [30] describes a case study as an empirical investigation that aims to ascertain a contemporary phenomenon within its real-life context. The author also explains that a case study is a good method for answering 'how' and 'why' questions. To conduct this case study, the five stages of the research model defined by Stuart et al. [31] were used (Figure 1).

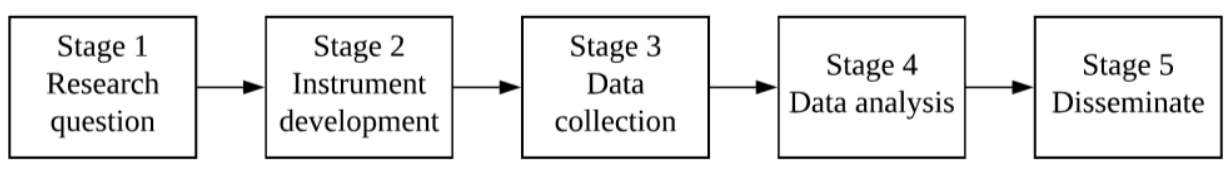

Figure 1: The five-stage research process model (Adapted from Stuart et al. [31])

As shown in Figure 1, this research presents the following characteristics:

- $\quad$ Stage 1 - Research question: How can a medium-sized furniture industry increase productivity by implementing LM tools and practices?

- $\quad$ Stage 2 - Instrument development: We developed a specific framework for furniture industries (the lean furniture framework) and used it as a guideline to implement lean manufacturing and data collection. We used the steps of the LFF to report the case study (Section 3).

- $\quad$ Stage 3 - Data collection: The data were collected by participation in meetings, through direct observation, from company and consultant reports, and through a semi-structured interview with a technical consultant who conducted the entire LM implementation process. 
- $\quad$ Stage 4 - Data analysis: The data were triangulated for the discussion of the study.

- $\quad$ Stage 5 - Dissemination: Disseminate the information through the publication of this article.

The next section presents the lean furniture framework used in this study.

\subsection{Framework for LM implementation in furniture sector SMEs}

A framework was developed by the authors to guide LM implementation in the SMEs of the furniture sector. The LFF was developed through a systematic literature review (SLR) that was conducted on LM implementation in small and medium enterprises (SMEs), with searches performed in the following databases: Scopus (Elsevier), Science Direct (Elsevier), Web of Science, Wiley Online Library, Academic Search Premier (ASP) (EBSCOhost), Emerald Insight, and SciELO. The database searches were performed on 08/18/2018, and resulted in 718 articles. After reading the titles, abstracts, introductions, and conclusions, 95 articles were selected.

From these 95 articles we identified 36 critical success factors (CSFs), 55 LM tools and practices, and 19 initiatives to implement LM in SMEs. From these 19 initiatives we selected the following frameworks as the foundation for LFF development: Belhadi, Touriki and Fezazi [13], Dombrowski, Crespo and Zahn [15], Hu, Mason, Williams and Found [16], and Medbo and Carlsson [17]. Table 1 summarises the items from each framework that were used to construct the LFF.

Table 1: Summary of each framework that was used to construct the LFF (Source: Researchers' own construction)

\begin{tabular}{c|l}
\hline Articles & \multicolumn{1}{c}{ Items from each framework } \\
\hline $\begin{array}{c}\text { Dombrowski et } \\
\text { al. [15] }\end{array}$ & $\begin{array}{l}\text { Steps necessary for implementing LM in SMEs: Basic planning (centralised), setting up } \\
\text { (centralised), rollout (decentralised), daily operations (decentralised). }\end{array}$ \\
\hline $\begin{array}{c}\text { Medbo \& Carlsson } \\
\text { [17] }\end{array}$ & Methodology: 'The wave’. \\
\hline Hu et al. [16] & Lean staircase road map: evolutionary ladder for LM implementation. \\
\hline $\begin{array}{c}\text { Belhadi et al. } \\
\text { [13] }\end{array}$ & $\begin{array}{l}\text { Three stages: Preparation (pre-implementation), execution (implementation), and } \\
\text { generalisation (post-implementation). }\end{array}$ \\
\hline
\end{tabular}

At this point, we have the first version of the framework used to conduct semi-structured interviews with experts in the furniture industry. During the interviews, the experts emphasised that the majority of the furniture industry has no knowledge about LM. They also emphasised that the approach used by the LFF must be the initial focus of presenting LM as a toolbox for productivity improvement and waste reduction, because this approach is most promising in demonstrating the benefits of LM for SMEs. As results of the interviews, we incorporated the pilot project approach and we defined the set of activities, practices, tools, and participants at each of the LM implementation steps in line with the experts' experiences and the literature findings (Table 2).

The framework proposes an evolutionary ladder for LM implementation, inspired by Pettersen [4] and Hayes and Wheelwright [32]. The first stage of LM implementation is defined as operational practices (toolbox lean) in which companies consider LM only as a set of tools for reducing operational waste.

In the second stage, operational philosophy (leanness), the production system has already adopted the LM philosophy and reached the lean state. In this case, the companies implement $L M$ in an integrated way, improving the flow of production. In the third stage, strategic practices (becoming lean), the company goes beyond operational concepts and adopts LM tools at a strategic level; specifically, there is planning based on LM principles. Here, the adoption of the lean office also begins.

In the last stage of implementation, strategic philosophy (lean thinking), LM conducts all strategic business and organisational planning following Hoshin planning. At this stage, the company reaches the Toyota Way [33]. 


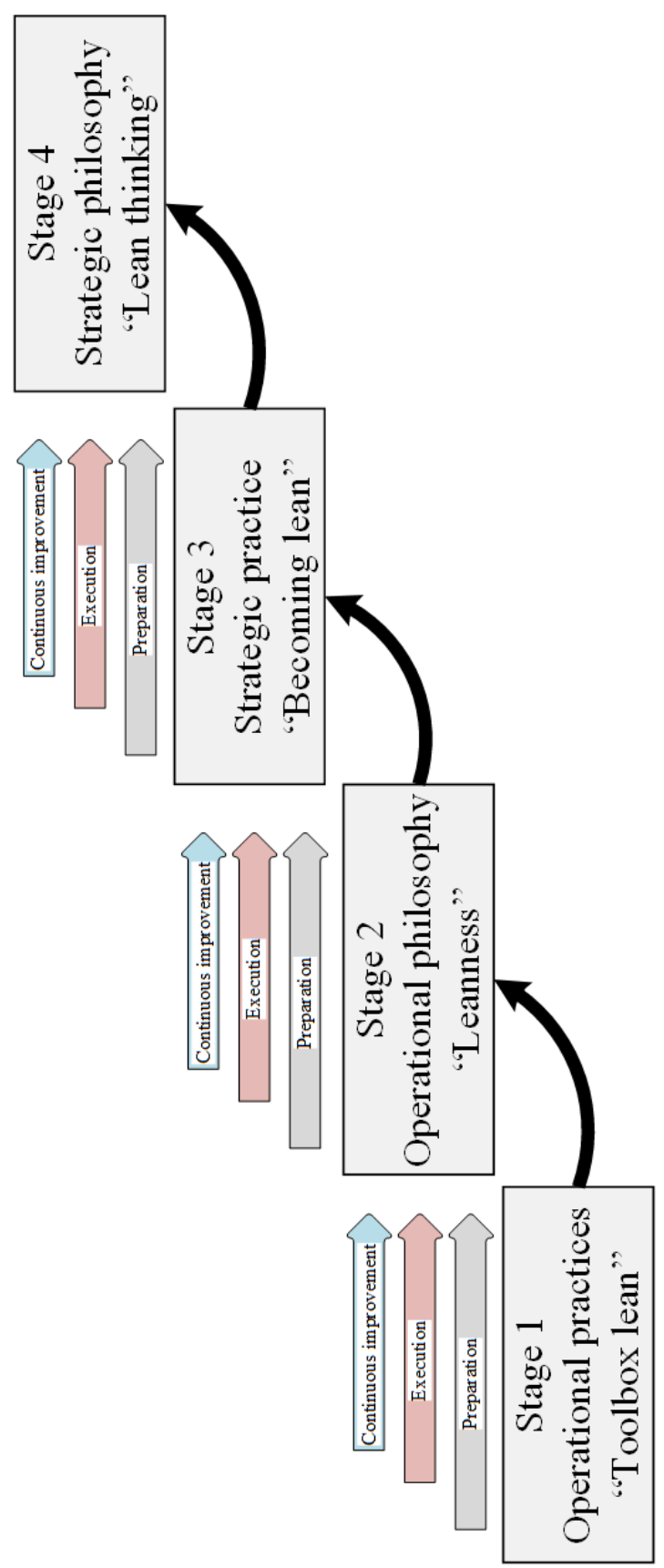

Figure 2: Lean furniture framework (Source: Researchers' own construction, based on Pettersen [4] and Hayes \& Wheelwright [32])

To evolve through the framework stages, a procedural approach was elaborated (Figure 3 and Table 2), divided into phases, stages, and activities. Three phases were defined: preparation, execution, and continuous improvement, which are represented in the framework as the arrows above the stages (Figure 2). These phases are divided into five major steps (Figure 3): (1) LM diagnostic; (2) planning the LM implementation project; (3) executing and monitoring the pilot projects; (4) LM deployment; and (5) assessment of the implementation. Then each step is divided into a set of activities, along with the suggested practices, tools, and participants (Table 2). These activities were developed based on the systematic literature review and, mainly, on the opinion of the experts.

The next section presents the case study. 


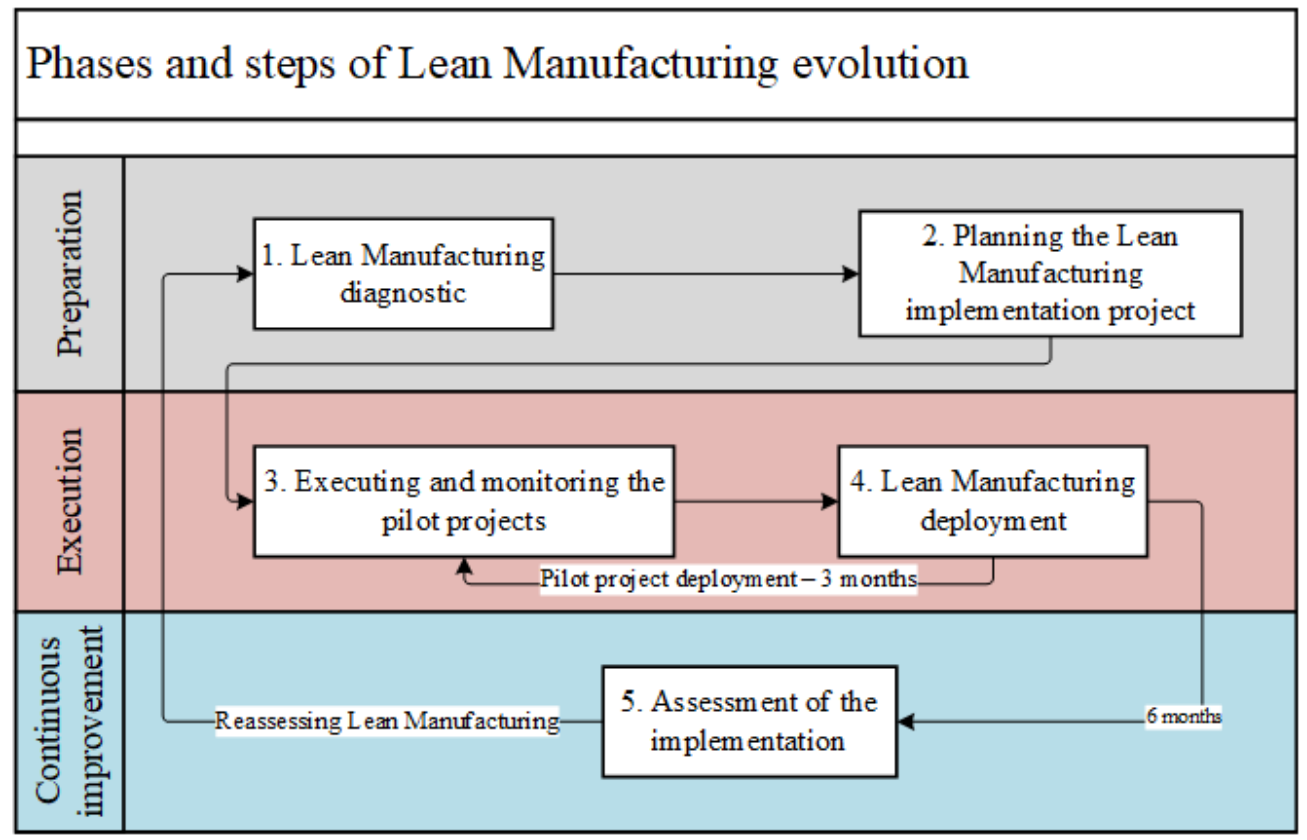

Figure 3: Lean furniture framework phases and steps (Source: Researchers's own construction)

\section{CASE STUDY}

This case study presents the partial implementation of LM to increase the productivity of a furniture industry, following the lean furniture framework (LFF). The company in this case study operates in the living room furniture segment, and has operated for more than 25 years in the furniture sector. The company's main focus is to serve the domestic market. Its main customers are large retailers, but the company also has a special line for furnishing interior decoration stores. The company's basic raw materials are medium density particleboard (MDP) panels, and the company's production is divided into five major departments: (1) cutting; (2) edge gluing; (3) machining; (4) painting; and (5) packaging. These departments group together a number of similar machines. Production, in most cases, follows the same flow, in terms of the sequence of departments, going through all production operations. It is important to note that this LM implementation was monitored by a technical consultant specialising in LM and the furniture industry.

The first stage is the preparation, detailed below.

\subsection{Phase 1: Preparation}

This phase of the framework is characterised by the preparation for LM implementation. The first step is LM diagnostic, in which the objective is to define the company's stage in the evolutionary ladder proposed by the framework (Figure 2). Then, with this information, the LM implementation project planning is carried out. In this step, all of the company's limitations (including time, costs, participants, and training) are considered.

\subsubsection{Step 1: Lean manufacturing diagnostic}

Initially, before applying the LM diagnostic form, the framework was presented and explained to the company representatives. Afterwards, the diagnostic form was presented to them, and a brief discussion was conducted by the consultant to identify the stage in which the company was located on the evolutionary ladder proposed by the framework. There was a consensus among all those present that the company was in the first stage: operational practices - toolbox lean. At this stage of the study, due to its strictly operational nature, the diagnostic forms for stage 1 and stage 2 were used. The diagnosis was based on the opinions of the production manager, engineering coordinator, a representative from production planning and control (PPC), and through direct observation on the factory floor. Figure 4 presents the results of the form application. 
Table 2: Detailed phases, steps, and activities (Source: Researchers' own construction)

\begin{tabular}{|c|c|c|c|c|}
\hline Phases & Steps & Activities & Practices/tools & $\begin{array}{l}\text { Suggested } \\
\text { participants }\end{array}$ \\
\hline \multirow[b]{2}{*}{ 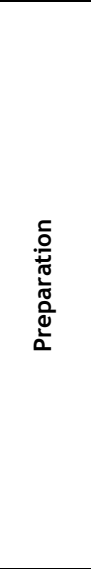 } & $\begin{array}{l}\text { 1. Lean } \\
\text { manufacturing } \\
\text { diagnostic }\end{array}$ & $\begin{array}{l}\text { 1.1. Evaluate the current level of } \\
\text { adherence of the furniture industry } \\
\text { to LM }\end{array}$ & $\begin{array}{l}\text { - Lean manufacturing } \\
\text { diagnostic form }\end{array}$ & $\begin{array}{l}\text { - Preferably a person } \\
\text { outside the } \\
\text { organisation. }\end{array}$ \\
\hline & $\begin{array}{l}\text { 2. Lean } \\
\text { manufacturing } \\
\text { implementation } \\
\text { planning }\end{array}$ & $\begin{array}{l}\text { 2.1. Define the LM approach; } \\
\text { 2.2. Define the LM implementation } \\
\text { scope (limit of action); } \\
\text { 2.3. Define the objectives of the LM } \\
\text { implementation; } \\
\text { 2.4. Define performance indicators; } \\
\text { 2.5. Define the implementation } \\
\text { team and the process improvement } \\
\text { committee; } \\
\text { 2.6. Define the necessary training } \\
\text { for project participants; } \\
\text { 2.7. Perform the value stream } \\
\text { mapping (VSM) of the current state, } \\
\text { identify the opportunities for } \\
\text { improvement, and elaborate the } \\
\text { VSM of the future state for the } \\
\text { implementation scope. }\end{array}$ & $\begin{array}{l}\text { - Teamwork; } \\
\text { - Workshops; } \\
\text { - Value stream mapping; } \\
\text { - Elaborate a 'senior } \\
\text { management commitment } \\
\text { contract with LM } \\
\text { implementation' to ensure } \\
\text { support and resource } \\
\text { availability; } \\
\text { - Evaluate hiring a } \\
\text { consultant. }\end{array}$ & $\begin{array}{l}\text { - Project } \\
\text { implementation } \\
\text { manager; } \\
\text { - Representative from } \\
\text { organisation's board } \\
\text { of directors; } \\
\text { - Managers (or } \\
\text { representatives) of } \\
\text { the areas affected by } \\
\text { the implementation. }\end{array}$ \\
\hline \multirow[t]{2}{*}{ 号 } & $\begin{array}{l}\text { 3. Execution and } \\
\text { follow-up of } \\
\text { pilot projects }\end{array}$ & $\begin{array}{l}\text { 3.1. Define the scope of the pilot } \\
\text { project; } \\
\text { 3.2. Collect and analyse detailed } \\
\text { data on the process to be improved; } \\
\text { 3.3. Estimate the necessary } \\
\text { resources (physical, financial, } \\
\text { human, administrative); } \\
\text { 3.4. Define the actions necessary for } \\
\text { improvement and establish a plan of } \\
\text { action (schedule); } \\
\text { 3.5. Supervised implementation of } \\
\text { improvement actions in kaizen } \\
\text { projects; } \\
\text { 3.6. Monitoring of activities using } \\
\text { gemba ('go and see' approach); } \\
\text { 3.7. Compare planned vs } \\
\text { accomplished; } \\
\text { 3.8. Critical evaluation of the } \\
\text { implementation process. }\end{array}$ & $\begin{array}{l}\text { - Teamwork; } \\
\text { - Workshops; } \\
\text { - Value stream mapping; } \\
\text { - LM tools (as needed); } \\
\text { - Project management } \\
\text { approach to } \\
\text { implementation; } \\
\text { - Audits. }\end{array}$ & $\begin{array}{l}\text { - Implementation } \\
\text { team; } \\
\text { - Employees directly } \\
\text { involved in the } \\
\text { activities; } \\
\text { - Process } \\
\text { improvement } \\
\text { committee; } \\
\text { - Project manager; } \\
\text { - Management } \\
\text { representative. }\end{array}$ \\
\hline & $\begin{array}{l}\text { 4. Lean } \\
\text { Manufacturing } \\
\text { Deployment }\end{array}$ & $\begin{array}{l}\text { 4.1. Define a new scope for the pilot } \\
\text { project; } \\
\text { 4.2. Repeat activities } 3.2 \text { to } 3.7 \\
\text { (three-month cycles). }\end{array}$ & $\begin{array}{l}\text { - Teamwork; } \\
\text { - Workshops; } \\
\text { - Value stream mapping; } \\
\text { - LM tools (as needed); } \\
\text { - Project management } \\
\text { approach to } \\
\text { Implementation; } \\
\text { - Audits. }\end{array}$ & $\begin{array}{l}\text { - Implementation } \\
\text { team. } \\
\text { - Employees directly } \\
\text { involved in the } \\
\text { activities. } \\
\text { - Process } \\
\text { improvement } \\
\text { committee. } \\
\text { - Project manager. } \\
\text { - Management } \\
\text { representative. }\end{array}$ \\
\hline 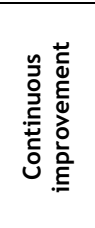 & $\begin{array}{l}\text { 5. Assessment of } \\
\text { the } \\
\text { implementations }\end{array}$ & $\begin{array}{l}\text { 5.1. Monitor results at the end of } \\
\text { implementation projects (six-month } \\
\text { cycles); } \\
\text { 5.2. Re-evaluate the level of } \\
\text { adherence of the furniture industry } \\
\text { to LM. }\end{array}$ & $\begin{array}{l}\text { - Teamwork; } \\
\text { - Workshops; } \\
\text { - Audits; } \\
\text { - Lean manufacturing } \\
\text { diagnostic form. }\end{array}$ & $\begin{array}{l}\text { - Process } \\
\text { improvement } \\
\text { committee. } \\
\text { - Implementation } \\
\text { team. } \\
\text { - Project manager. } \\
\text { - Management } \\
\text { representative. }\end{array}$ \\
\hline
\end{tabular}

In Figure 4, the red line represents the current level of implementation of the LM practices and tools identified in the company. In the diagnostic form, level 1 means 'no tool use', while level 5 means that culture change has been achieved. As noted, the company has adopted few LM practices and tools, which confirms its classification within the first stage of LM implementation. These results were presented at the beginning of the LM implementation planning meeting, as detailed below. 

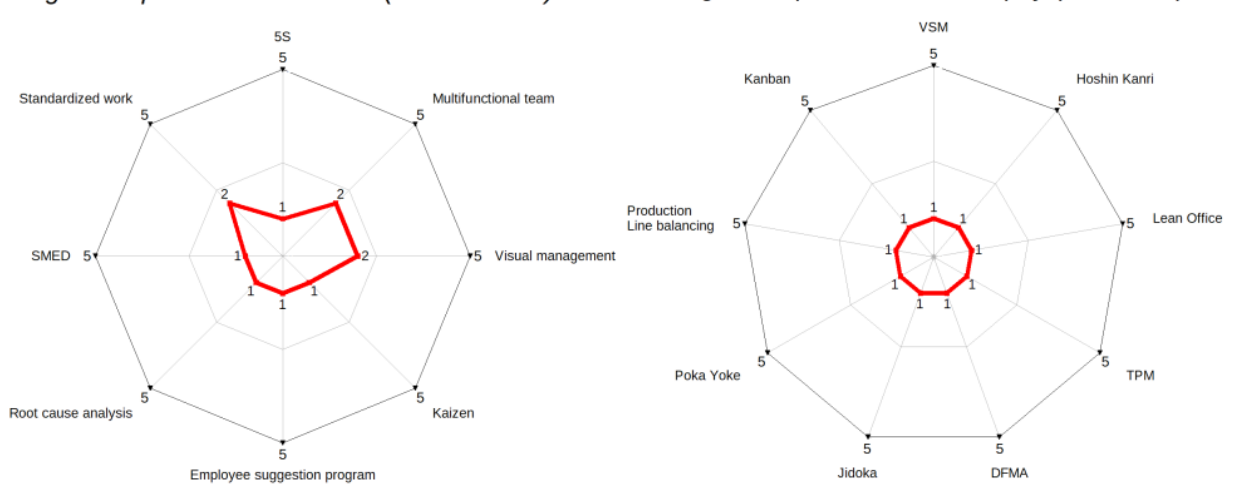

Figure 4: Results of lean manufacturing diagnostic (Source: Researcher's own construction)

\subsubsection{Step 2: Lean manufacturing implementation planning}

After the diagnosis, the researchers, consultant, production manager, engineering coordinator, and a representative from PPC met to plan the LM implementation. This group analysed the results of the LM diagnosis and defined some goals, the main one of which was to achieve level 2 in all LM practices and tools of the stage 1 in a period of one year. During the three-month case study, the group conducted the LM implementation using the detailed activities in Table 1, and defined the lean manufacturing implementation planning, shown in Table 3. These activities were developed at three different times. First, there was an initial meeting in which the researchers, the consultant, the production manager, the engineering coordinator, and a representative from PPC were present. At that meeting, activities (2.1) and (2.2) were discussed and carried out. Second, the VSM of the current state was developed for the defined scope, which is part of the activity (2.7). This mapping was developed by the consultant with the participation of the production manager, engineering coordinator, and a representative from PPC. Third, a new meeting was held to carry out activities (2.4), (2.5), and (2.6) and to finalise activity (2.7). It is important to emphasise that the researchers acted as observers, limiting themselves to answering questions about the framework.

Table 3 - Step 2 results (Source: Researcher's own construction)

\begin{tabular}{|c|l|}
\hline Activities & \multicolumn{1}{|c|}{ Results } \\
\hline$(2.1)$ & Stage 1 - Operational practices (Toolbox lean) \\
\hline$(2.2)$ & $\begin{array}{l}\text { Partial implementation of LM for the production line of the rack product family, considering } \\
\text { the restrictions of three months, budget of 18,000.00 BRL, and availability of employees for } \\
\text { four hours per week. }\end{array}$ \\
\hline$(2.3)$ & $\begin{array}{l}\text { Increase productivity by 20\%; } \\
\text { Reduce movement by 30\%. }\end{array}$ \\
\hline$(2.4)$ & $\begin{array}{l}\text { Productivity = pieces produced per day; } \\
\text { Movement = meters during activity execution; } \\
\text { Annual rate of return (\%) = (monthly cost reduction * 12 * 100) / amount invested }\end{array}$ \\
\hline$(2.5)$ & $\begin{array}{l}\text { Implementation team = production manager, sector supervisor, machine operator and } \\
\text { assistant machine operator. } \\
\text { Process improvement committee = production manager, engineering coordinator, and a } \\
\text { representative from PPC. }\end{array}$ \\
\hline$(2.6)$ & Value stream mapping (VSM); single minute exchange of die (SMED); and standard work. \\
\hline
\end{tabular}

To finalise the planning stage, it is necessary to elaborate on the VSM of the current state, to identify the opportunities for improvement, and to elaborate on the VSM of the future state. To this end, data on the company's products were collected to identify the family of products with the largest sales volume, and then to delimit the scope for the VSM. After collecting this data, a Pareto chart was created that identified the rack product family as the most relevant for the company, considering the sales volume. With this information, the VSM of the current state was elaborated using a systemic approach that prioritised the most critical item of the final product that would affect getting the product into its packaging. This is because a rack is currently produced by components in multiple batches of 80 , indicative of pushed and mass production. In addition, the 
furniture industry is characterised by having several shared machines, which makes elaborating the VSM difficult. Based on this information, the most critical component of the rack product was determined to be the front footer component, which is grouped together with the other components in the packaging sector. The front footer also represents a large volume of production, and is used in other products. Figure 5 is the result.

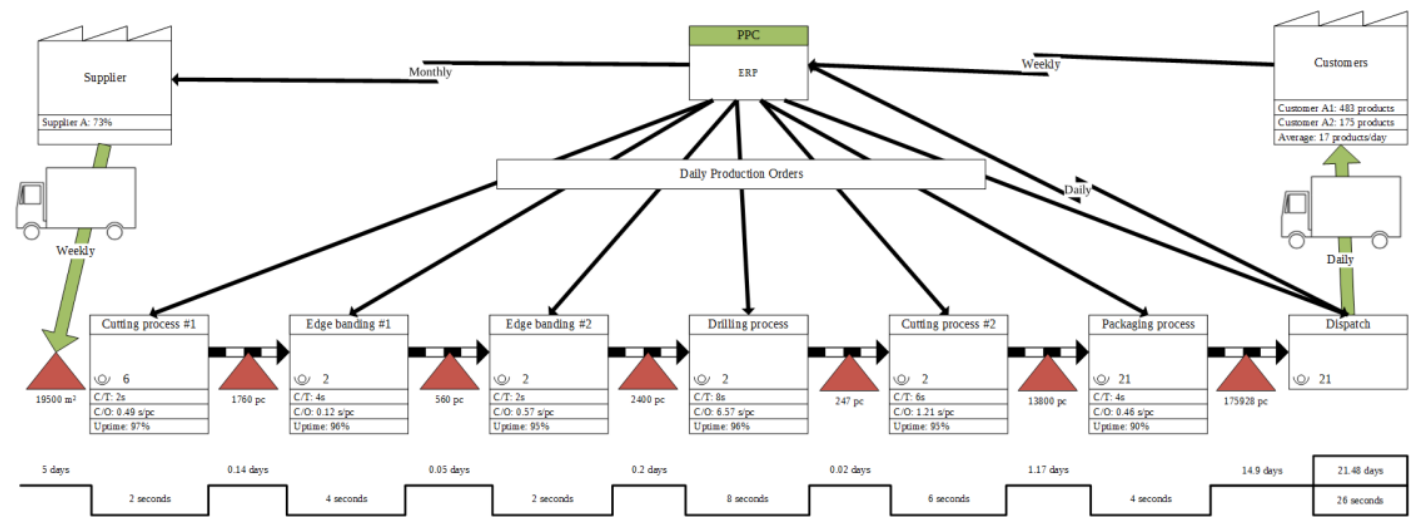

Figure 5: VSM current state (Source: Researcher's own construction)

With shared resources, the takt time calculation becomes a challenge because, in traditional VSM approaches [34], resources are dedicated; but this is not the case in the furniture industry. Therefore, to define the available time of the resources for the front footer component, we considered the volume of parts that the component represents within the plant, which is $12 \%$. Based on this, we considered that the time available for the production of this component per day was equivalent to 12 per cent of eight hours of work - that is, 57.6 minutes. In a given shift, approximately 990 pieces are produced. Considering these values, a takt time of 3.5 seconds was calculated.

From Figure 5, the value-adding time was observed to be 26 seconds, and the lead time was 21.48 days. Thus the company had a value-adding of 0.037 per cent for this product. To define the scope of implementation, it was also necessary to expand the VSM based on the takt time analysis, the cycle times of the operations, and the in-process inventory. When analysing the cycle time of each operation and comparing this time with the takt time (Figure 6), four operations having a longer time were observed: skirting 1 , drilling, cutting 2 , and packaging.

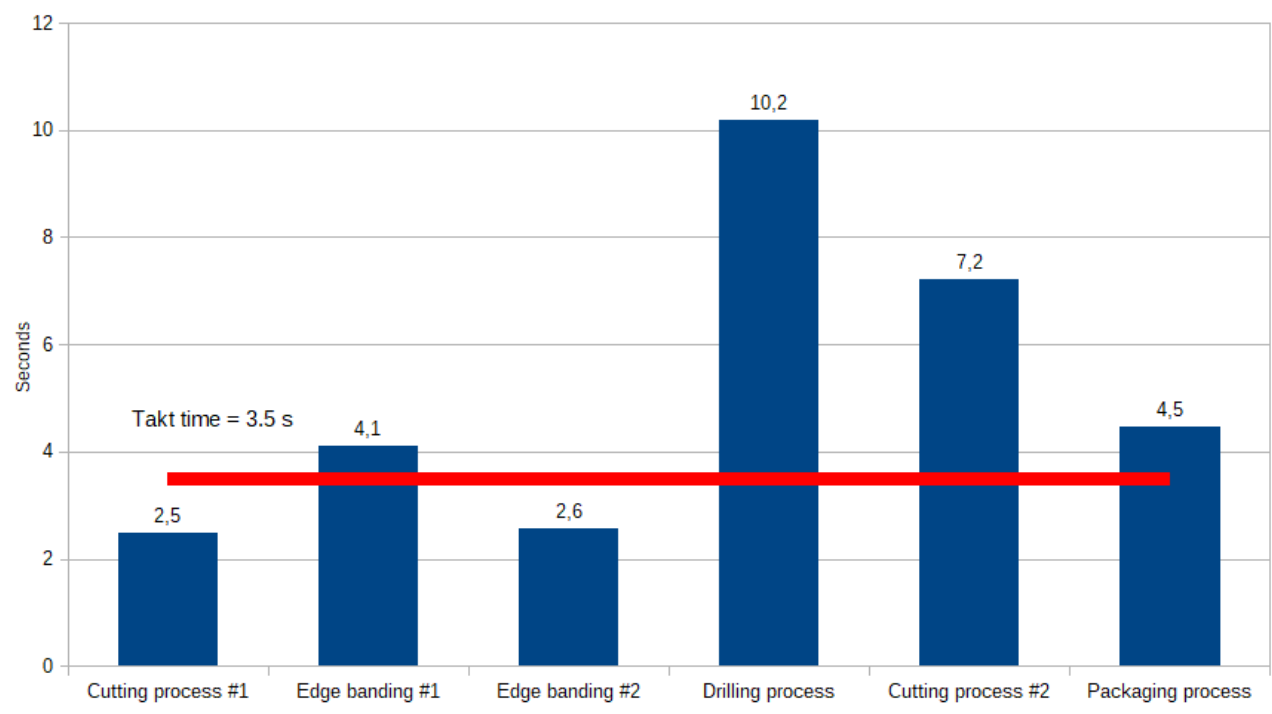

Figure 6: Cycle time of operations (Source: Researcher's own construction) 
The drilling operation had the longest cycle time, well above the takt time, which indicated a need for priority improvement. Next, to complement the analysis, the in-process inventory before the operations was also verified (Figure 7).

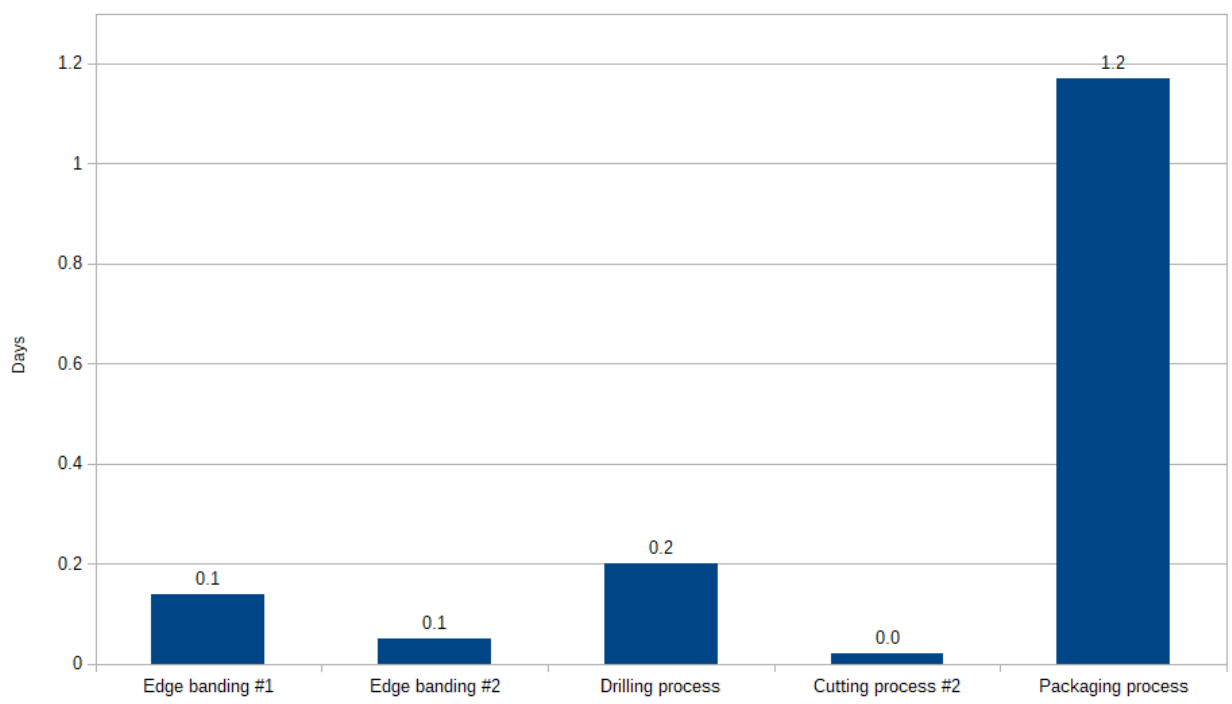

Figure 7: Inventory before operations (in days) (Source: Researcher's own construction)

The cutting 1 and dispatch operations were excluded to focus the analysis on the component's main value chain. The inventory prior to the packaging operation is the greatest, but this operation receives all the components of the previous operations to pack the final product; thus the large volume of parts is understandable. The drilling operation has the second-largest amount of inprocess inventory. Based on the data collected and analysed, the points for improvement were identified, and a VSM of the future state was proposed (Figure 8). Analysing the necessary points for improvement, the two most critical operations were drilling and cutting 2 . In drilling, the following problems were identified: setup, movement, incorrect production, and checking. In cutting 2, problems were identified in the following: rework, maintenance, movement, and balancing between the stages of the production process. These problems were identified from the analysis of the VSM current state carried out by the process improvement committee. Given these problems, the focus of improvement would be the drilling operation because it had the longest cycle time and the secondlargest in-process stock of the value chain.

Considering the points highlighted above, the improvement would occur in the drilling operation setup. This machine performs at least three setups per day, each lasting about 36 minutes, which takes up a considerable amount of time from the machine. In addition, even eliminating the setup completely would not solve the problem, because the machine's operating cycle time (eight seconds) is longer than the takt time ( 3.5 seconds). Considering the deadline and the budget available for executing the project, the improvement was limited only to the setup of the operation. At the end, improvements were identified in order for the company to continue the implementation project.

\subsection{Phase 2: Execution}

In this phase, the objective is to work with smaller implementation scopes in the form of pilot projects. Doing so implies breaking down the scope defined for LM implementation into smaller scopes to reduce the complexity and obtain a faster return on the developed actions. This breakdown helps to reduce one of the demotivating factors of LM implementation: complexity and delays in obtaining results [35]. 


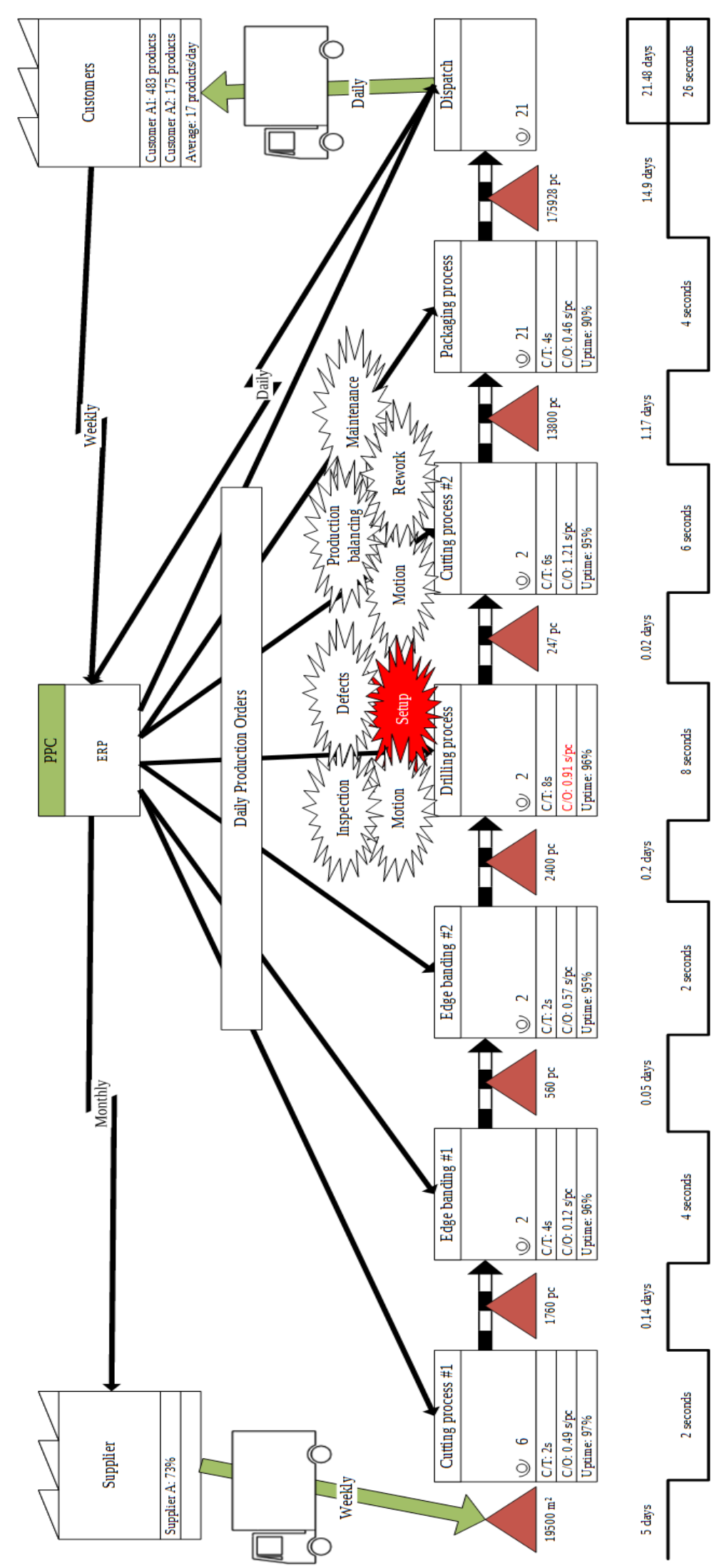

Figure 8: VSM future state (Source: Researcher's own construction) 


\subsubsection{Step 3: Execution and follow-up of pilot projects}

In this step, everyone involved in LM implementation participates in the pilot project to learn the implementation process so that they can then execute the LM deployment stage (step 4). The deployment consists of expanding the learned knowledge to other areas of the company. In this step, the following activities are performed, detailed in Table 1: (3.1) define the scope of the pilot project; (3.2) collect and analyse detailed information on the process to be improved; (3.3) estimate the necessary resources (physical, financial, human, administrative); (3.4) define the actions necessary for improvement and establish a plan of action (schedule); (3.5) supervise the implementation of improvement actions in kaizen projects; (3.6) monitor activities using gemba ('go and see' approach); (3.7) compare what was planned with what was accomplished; and (3.8) critically evaluate the implementation process.

Based on the scope of implementation and the VSM, the scope of the pilot project (3.1) was determined: (a) reduce the setup time of the LIDEAR F500 drilling machine to 15 minutes; (b) establish a standard for executing the setup (standardised work); and (c) move production closer to the daily production target (3,500 units/day). We selected the LIDEAR F500 because it was the oldest and most technologically outdated machine that the machining department used for drilling. The data collected on this machine were the number of pieces produced per day (Figure 9) and the mean setup time per day (Figure 10) (3.2). These measurements were made between November 22, 2016 and December 15, 2016. The process improvement committee defined the resources needed to carry out this pilot project (3.3): training, specialised consulting, camcorder, machine availability, and employees.

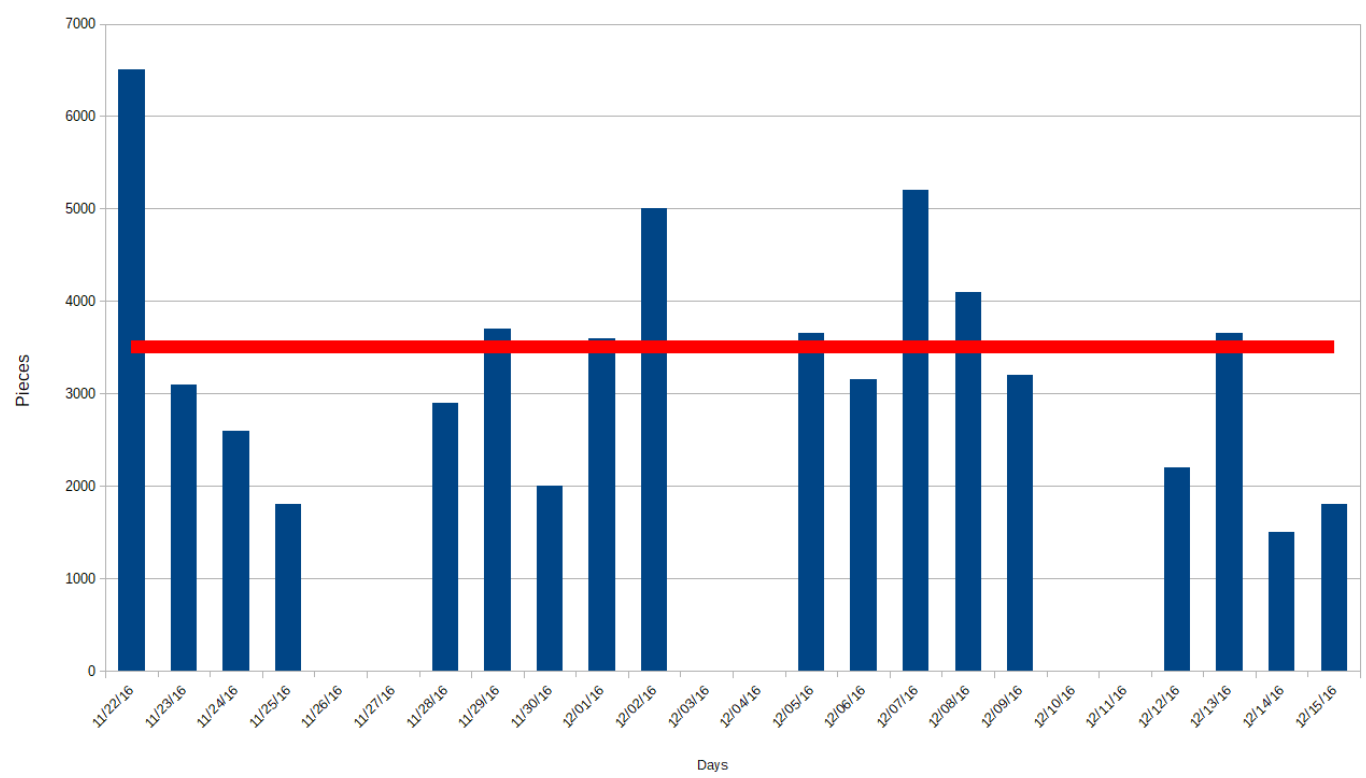

Figure 9: Number of pieces produced (Source: Researcher's own construction)

As shown in Figure 9, during the 18-day follow-up the LIDEAR F500 machine achieved an average production rate of approximately 3,314 pieces per day, which was close to the daily production target of 3,500 pieces per day. Almost every day the mean setup time was greater than the goal of 15 minutes. The overall mean setup time over the 18-day follow-up period was about 25 minutes. Based on this information, a set of necessary actions for implementation (3.4) was elaborated on, and is presented in Table 4 in a schedule format. 


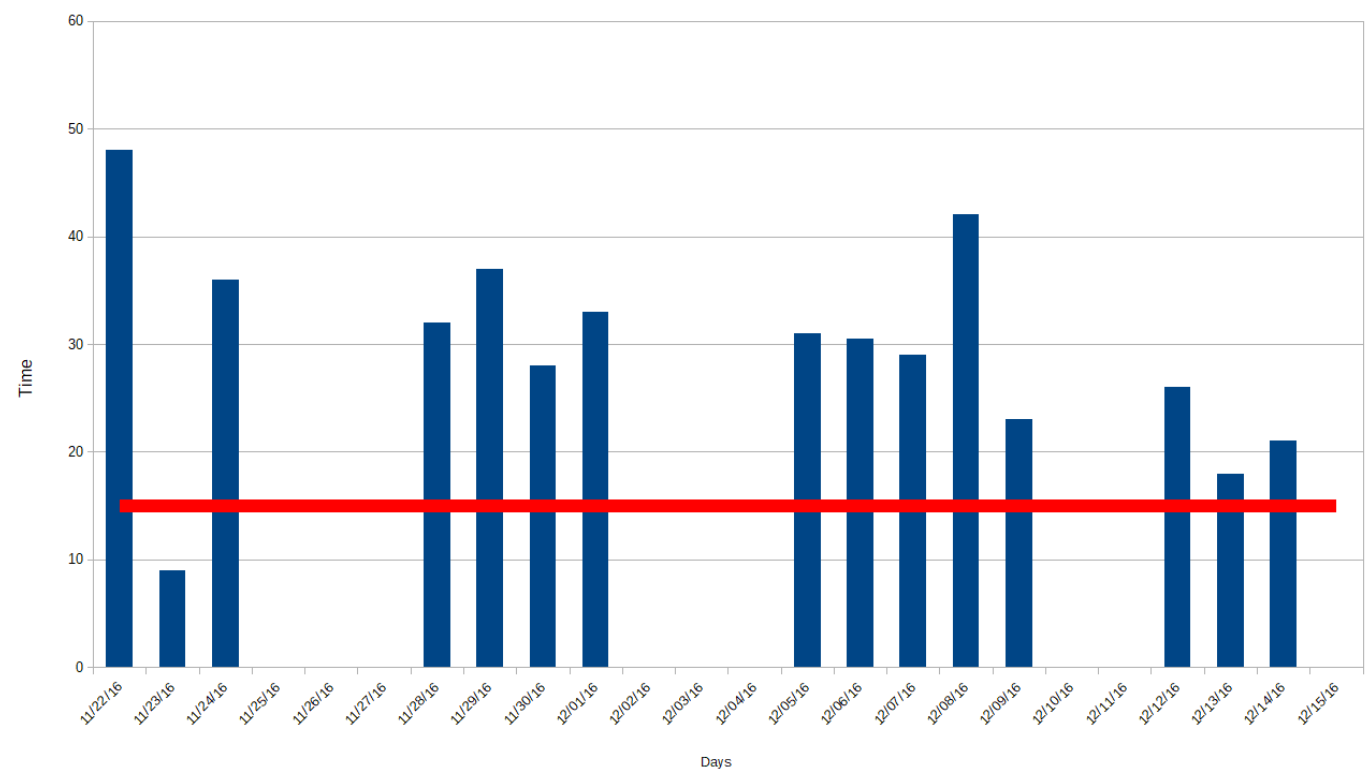

Figure 10: Average setup time per day (Source: Researcher's own construction)

Table 4: Schedule of the pilot project (Source: Researcher's own construction)

\begin{tabular}{|l|l|l|l|l|}
\hline \multicolumn{1}{|c|}{ Improvement actions } & Nov/17 & Dec/17 & Jan/18 & Feb/18 \\
\hline Training in VSM, SMED, and standard work & & & & \\
\hline Survey of machine information on LIDEAR F500 & & & & \\
\hline Analysis of the current state & & & & \\
\hline Drawing of the future state & & & & \\
\hline Implementation of the future state & & & & \\
\hline Standardisation of improvement actions & & & & \\
\hline
\end{tabular}

Follow-up meetings were scheduled every 15 days, and a set of actions to be implemented between the meetings was established. Based on the data collected, the current state was analysed using a spaghetti diagram to determine the movements when executing the setup (Figure 11). From the diagram, the operator and the assistant move 276 meters to execute the setup over about 36 minutes. The analysis of the setup was performed based on the three stages setup improvement created by Shingo [36]: (1) Separating internal and external setup; (2) Converting internal to external setup; and (3) Streamlining all aspects of the setup operation. During setup, the operator and assistant lost considerable time interpreting the drilling plan, locating the required bits, and requesting assistance from PPC. The following improvement points were developed: an activity plan for executing the setup, a visual management panel to control the setup, a standardised operating procedure, a new proposed drilling plan, an organising box to separate the drill bits, and a visual management panel for the programming of parts to be drilled.

The next step was activity (3.5), supervised implementation of improvement actions in kaizen, which took about 30 hours. The purpose of this supervision was learning, since the goal was for the implementation team members and the process improvement committee to learn the step-by-step procedure for LM implementation with the help of the consultant and the researcher. An example of this process was the elaboration of the plan of activities for the setup of the LIDEAR F500 machine. The setup filming, spaghetti diagram elaboration, and SMED tool application activities were observed by the operator and assistant, who mainly helped to define the set of activities required to perform the setup. The activities for which the operator and assistant were responsible for were separated to reduce the setup time to less than 15 minutes. 


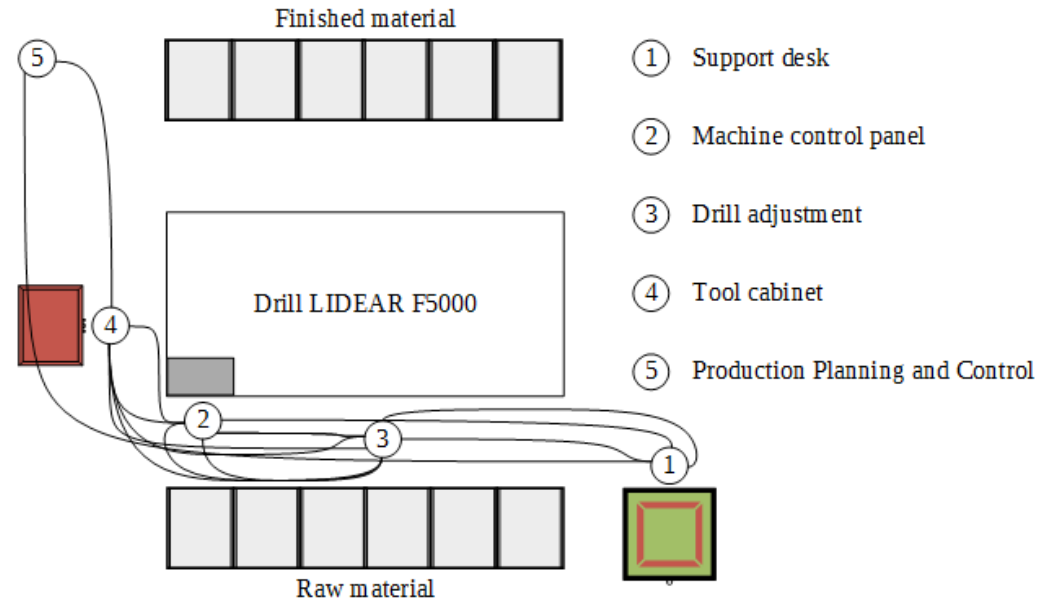

Figure 11: Spaghetti diagram (Source: Researcher's own construction)

The other improvement activities were carried out under the supervision of the consultant, who supported the members of the implementation team. Another point also emphasised and carried out by the process improvement committee was (3.6) - follow-up of activities using gemba ('go and see' approach). This approach emphasises the importance of the implemented improvement, and helps to maintain the established standard. It is advisable to perform this activity at least twice a week, carrying out a brief audit of the implemented improvements.

Meetings were held every 15 days with the members of the implementation team, the process improvement committee, the consultant, and the researcher to monitor the activities. At these meetings, which lasted about an hour, the planned and accomplished activities were compared, which involved evaluating the implementations and critically evaluating the LM implementation process. The difficulties encountered in implementing the activities were also discussed to identify the points to be improved and reinforced. In some meetings, the SMED and standard work training was reinforced. The adequacy of the approach used for the LM implementation was also discussed, which was fundamental for improving the framework. These meetings represented the development of activity (3.7), comparing what was planned with what was accomplished, and activity (3.8), critical evaluation of the implementation process.

All of these activities were carried out within the three-month deadline - the limit stipulated by the company for executing the activity. At the end, the improvements performed generated the results presented in Table 5.

Table 5: Pilot project results (Source: Researcher's own construction)

\begin{tabular}{|c|c|c|c|c|}
\hline Indicator & Initial measurement & Objectives & Final measurement & Results \\
\hline Productivity & 1330 pieces/day & $20 \%$ & 1686 pieces/day & $27 \%$ \\
\hline Movement & 276 meters & $30 \%$ & 184 meters & $33 \%$ \\
\hline \multicolumn{4}{|r|}{ Monthly cost reduction } & 1,322.29 BRL \\
\hline \multicolumn{4}{|r|}{ Return on investment } & 13.61 months \\
\hline
\end{tabular}

Unfortunately, step 4 (lean manufacturing deployment) did not run because no time was available, due to the three-month deadline for conducting the case study. Therefore, together with the process improvement committee, the consultant and the researcher developed a set of guidelines for implementing step 4, LM deployment, suggesting the extension of the knowledge developed about the LIDEAR F500 machine to the other machines in the machining department. This activity would be the responsibility of the process improvement committee.

\subsection{Phase 3: Continuous improvement}

Every six months it is appropriate to make a critical assessment of the entire LM implementation project. This assessment identifies the difficulties confronted and the points to be improved, and reviews the project plan. 
The objective of the evaluation stage of the implementation is to maintain the LM evolution cycle so that the company develops with each new pilot project. To achieve the second stage of the framework, for example, the company needs to fully master the VSM tool and use it to make processoriented improvements to the production flow, not just one-off improvements to single machines.

\subsubsection{Step 5: Assessment of the implementation}

At this stage, the following activities are conducted: (5.1) monitor the results at the end of project implementation (six-month cycles), and (5.2) re-evaluate the company's level of adherence to LM.

Activity (5.1) involves a critical analysis of the implementation project every six months. This activity should be performed by the process improvement committee, which also performs activity (5.2) at the same time. This activity consists of reapplying the LM diagnostic form. After carrying out these activities, it is advisable to re-evaluate the LM implementation scope (activity 2.3) based on the new diagnosis and on the critical evaluation of the implementation. Then the company resumes the LM implementation cycle, evolving in small steps towards the Toyota Way [33].

\section{$4 \quad$ DISCUSSION AND LESSONS LEARNED}

The process improvement committee developed adequate support for the development of the pilot project, contributing process improvement ideas, following the kaizen project, encouraging the operator, assisting in the development of the activities, and conducting audits to ensure the implementation of the improvement actions. The results were achieved according to the objectives established at the beginning of the project. To be sure, this pilot project does not represent the full LM implementation, but only a small step within a long-term implementation.

Several challenges were faced during the case study. At the beginning, there was a delay in defining the process improvement committee because there was no adequate support from top management, which hampered the start of implementation. This delay negatively affected the research and, consequently, there was no time to conclude step 4. Furthermore, getting the employees involved in the activities was challenging. At first, for example, the operator and assistant showed no interest in improving the machine setup. However, after they had watched the setup shoot, they were able to visualise the improvements that could be made in the setup, and were involved in the improvement.

In summary, the main contributions of this case study to the furniture industry were:

- A new way of work was presented for facing production system difficulties using the LFF and LM tools to help the analysis and to solve problems;

- $\quad$ There was cooperation from factory floor workers to generate solutions to the problems. This participation created greater involvement in the development of improvement activities, which was not usual for the company;

- A new routine was created to analyse production problems periodically and critically. The paradigm shift in analysing and solving problems has brought new insights to the company, such as creating templates to perform the setup on all drilling machines, standardisation of external and internal setup on all drilling machines, and replication of setup improvement in the painting sector.

The pilot project was a catalyst for further actions within the company, which subsequently developed six additional projects. The framework presented a structured method of approaching LM, which was previously unknown to the company, as well as of identifying problems, presenting solutions, and generating cost reductions.

The main lessons learned from this research can be separated into the following topics:

- Lean manufacturing implementation in SMEs: there are several examples of research on LM implementation in SMEs [13-15, 37-41], but no specific research was identified for the furniture sector. Therefore, this research contributes when it presents in detail the initiative of the partial implementation of LM specifically in the furniture sector. The article also contributes by presenting empirical research that verifies the theory in collaboration with professionals 
[42]. Another contribution is the presentation of an adapted framework to develop research in an emerging country [43].

- Lean furniture framework: there are several frameworks for implementing LM in SMEs [5, 7, 8, 11-17, 40, 44-50], but there is no specific framework for the furniture sector. Thus the lean furniture framework is also a contribution of this article, because the LFF is specific to SMEs in the furniture industries. In addition, the LFF is an implementation framework [51], presenting stages of evolution and a structured set of steps and activities for the implementation of LM.

Corroborating Belhadi et al. [52], SMEs in Brazil are also affected by the lack of understanding of the $L M$, and this affects implementation. This research can be used as a basis for future comparisons between SMEs in developing countries, as highlighted by Belhadi et al. [52].

\section{CONCLUSION AND FUTURE STUDIES}

Although consolidated in many sectors, LM is still unknown to most SMEs in the Brazilian furniture sector. In recent years there have been major investments in LM dissemination to several production sectors in Brazil, and a major challenge has been establishing a structured approach for implementation. In the case of the furniture sector, there is great difficulty in accepting LM because of the production system adopted today, in which companies push production in mass quantities and have a large amount of work in process. With the support of experts, it was possible to develop a specific framework and partially to implement LM in a medium-sized furniture industry with the aim of transferring knowledge so that the company can multiply that knowledge later.

In this case study, based on the VSM, the drilling operation for the production of the front footer component of a family of rack products was the most critical, being well above the takt time projected for the component. Thus, considering the limitations established in the planning, a pilot project was carried out on the LIDEAR F500 drilling machine, which was the most technologically outdated. The responsibilities of the process improvement committee were defined as having the critical role of monitoring and strengthening the LM implementation. In addition, a routine was created to perform a structured critical analysis of the operational problems faced by the company. There was also a change in the elaboration of problem solutions by including the employees directly involved in the production activity. Finally, there was a productivity increase on the LIDEAR F500 drilling machine of 27 per cent and a reduction of movement of 33 per cent (Table 5). This represents a reduction in production costs, which resulted in an annual savings of approximately 15,800.00 BRL.

In summary, this article contributes to the LM literature by addressing some points highlighted by Jasti and Kodali [42, 43]. The article presents research developed in collaboration between academics and professionals in order to obtain "better results and useful research articles" [43]. It also contributes by presenting the research in an emerging country and "developing independent culture to promote lean principles across the globe" [43]. The research presents a systematic framework for furniture industries to implement LM principles across all operational and strategic activities.

The results presented in this article represent the partial application of the LM implementation framework in a medium-sized company in the furniture sector. This is the main limitation of the research: the conclusions are exclusive to this industry and to the context in which it operates. Therefore, in future research, more case studies need to be developed in furniture industries of different sizes to ascertain the applicability of the framework. Another limitation is that this case study has a purely operational focus; the strategic focus, represented by stages 3 and 4 of the LFF, is still in development. For this purpose, also in future research, it is appropriate to conduct longitudinal studies to follow the evolution of companies in $L M$, and thus to adapt the framework to meet all stages of evolution.

Although the LFF was created for furniture industries, the authors consider that it is possible to adapt the framework for other sectors, and also to use it as a way to compare LM implementation initiatives between emerging countries.

\section{REFERENCES}

[1] Womack, J., Jones, D. \& Roos, D. 1990. The machine that changed the world. New York: Rawson Associates. 
[2] Krafcik, J. 1988. The triumph of the lean production system. Sloan Management Review, 30(1), pp. 41-52.

[3] Modig, N. \& Åhlström, P. 2015. This is lean. Stocksund, Sweden: Rheologica Publishing.

[4] Pettersen, J. 2009. Defining lean production: Some conceptual and practical issues. The TQM Journal, 21(2), pp. 127-142. doi:10.1108/17542730910938137

[5] Achanga, P., Shehab, E., Roy, R. \& Nelder, G. 2006. Critical success factors for lean implementation within SMEs. Journal of Manufacturing Technology Management, 17(4), pp. 460-471. doi:10.1108/17410380610662889

[6] Dora, M., Kumar, M. \& Gellynck, X. 2015. Determinants and barriers to lean implementation in foodprocessing SMEs - a multiple case analysis. Production Planning \& Control, 27(1), pp. 1-23. doi:10.1080/09537287.2015.1050477

[7] Jeyaraman, K. \& Teo, L. 2010. A conceptual framework for critical success factors of lean Six Sigma: Implementation on the performance of electronic manufacturing service industry. International Journal of Lean Six Sigma, 1(3), pp. 191-215. doi:10.1108/20401461011075008

[8] Mamat, R., Deros, B., Rahman, M., Omar, M. \& Abdullash, S. 2015. Soft lean practices for successful lean production system implementation in Malaysia automotive SMEs: A proposed framework. Jurnal Teknologi, 77(27), pp. 141-150. doi: 10.11113/jt.v77.6910

[9] Rymaszewska, A.D. 2014. The challenges of lean manufacturing implementation in SMEs. Benchmarking, 21(6), pp. 967-1002. doi:10.1108/BIJ-10-2012-0065

[10] Shrimali, A. \& Soni, V. 2017. Barriers to lean implementation in small and medium-sized Indian enterprises. International Journal of Mechanical Engineering and Technology, 8(6), pp. 1-9. Available at: http://www.iaeme.com/MasterAdmin/UploadFolder/IJMET_08_06_001/IJMET_08_06_001.pdf

[11] Arcidiacono, G., Costantino, N. \& Yang, K. 2016. The AMSE Lean Six Sigma governance model. International Journal of Lean Six Sigma, 7(3), pp. 233-266. doi:10.1108/IJLSS-06-2015-0026

[12] Azyan, Z., Pulakanam, V. \& Pons, D. 2017. Success factors and barriers to implementing lean in the printing industry: A case study and theoretical framework. Journal of Manufacturing Technology Management, 28(4), pp. 458-484. doi:10.1108/JMTM-05-2016-0067

[13] Belhadi, A., Touriki, F. \& Fezazi, S. 2016. A framework for effective implementation of lean production in small and medium-sized enterprises. Journal of Industrial Engineering \& Management, 9(3), pp. 786810. doi:10.3926/jiem.1907

[14] Berlec, T., Kleindienst, M., Rabitsch, C. \& Ramsauer, C. 2017. Methodology to facilitate successful lean implementation. Strojniski Vestnik/Journal of Mechanical Engineering, 63(7-8), pp. 457-465. doi:10.5545/sv-jme.2017.4302

[15] Dombrowski, U., Crespo, I. \& Zahn, T. 2010. Adaptive configuration of a lean production system in small and medium-sized enterprises. Production Engineering, 4(4), pp. 341-348. doi:10.1007/s11740-010-0250-5

[16] Hu, Q., Mason, R., Williams, S. \& Found, P. 2015. Lean implementation within SMEs: A literature review. Journal of Manufacturing Technology Management, 26(7), pp. 980-1012. doi: 10.1108/JMTM-02-2014-0013

[17] Medbo, L. \& Carlsson, D. 2013. Implementation of Lean in SME, experiences from a Swedish national program. International Journal of Industrial Engineering and Management, 4(4), pp. 221-227. Available at: http://ijiemjournal.uns.ac.rs/images/journal/volume4/ijiem_vol4_no4_4.pdf

[18] Hu, Q., Mason, R., Williams, S. \& Found, P. 2016. The change of production systems through consultancy involved projects: A multiple case study in Chinese SMEs. Production Planning \& Control, 27(7-8), pp. 550562. doi:10.1080/09537287.2016.1165303

[19] Panizzolo, R., Garengo, P., Sharma, M. \& Gore, A. 2012. Lean manufacturing in developing countries: Evidence from Indian SMEs. Production Planning \& Control, 23(10-11), pp. 769-788. doi:10.1080/09537287.2011.642155

[20] Gonzales, E., Hommes, M. \& Mirmulstein, M. 2014. MSME country indicators 2014: Towards a better understanding of micro, small, and medium enterprises. Available at:

http://www.smefinanceforum.org/sites/all/modules/custom/sme_custom/datasites/analysis\%20note.pd f.

[21] Gnanaraj, S., Devadasan, S., Murugesh, R. \& Sreenivasa, C. 2012. Sensitisation of SMEs towards the implementation of Lean Six Sigma - an initialisation in a cylinder frames manufacturing Indian SME. Production Planning \& Control, 23(8), pp. 599-608. doi:10.1080/09537287.2011.572091

[22] Anand, G. \& Kodali, R. 2010. Analysis of lean manufacturing frameworks. Journal of Advanced Manufacturing Systems, 1(9), pp. 1-30. doi:10.1142/S0219686710001776

[23] Galinari, R., Teixeira Jr, J. \& Morgado, R. 2013. A competitividade da indústria de móveis do Brasil: Situação atual e perspectivas. BNDES Setorial 37 (mar.), pp. 227-272. Available at: http://web.bndes.gov.br/bib/jspui/handle/1408/1516.

[24] Oliveira, R., Stefenon, S., Branco, N., Oliveira, J. \& Rohloff, R. (2017) Lean manufacturing em associação à automação industrial: Estudo de caso aplicado à indústria moveleira. Espacios, 38(17), pp. 24-39. Available at: http://www.revistaespacios.com/a17v38n17/a17v38n17p24.pdf

[25] Vizzotto, M., Fredo, A., Ciconet, B., Rizzotto, M., Tondolo V. \& Zanandrea, G. 2015. Identificação das dificuldades de implantação da produção enxuta: Um estudo de caso no setor moveleiro. Espacios, 36(19), pp. 20-31. Available at: http://www.revistaespacios.com/a15v36n19/15361920.html

[26] Stahlhofer, E., Luz, R., Pessa, S., Laperuta, D. \& Luz, J. 2016. Implantação de ferramentas Lean em pequenas e médias empresas: Estudo de caso em uma indústria moveleira. Espacios, 37(37), pp. 15-20. Available at: http://www.revistaespacios.com/a16v37n37/16373716.html 
[27] Viana, A., Lucas Filho, F., Mellom, M., Santos, R., Lacerda, F., Lira, H., Santos, W., Medeiros, C., Bezerra, S., Neto, N. \& Freitas, C. 2017. Redução de custos que não agregam valor via melhoria de processos: Estudo de caso na produção de móveis. Espacios, 38(43), pp. 15-29. Available at: http://www. revistaespacios.com/a17v38n43/a17v38n43p15.pdf.

[28] Araújo, C.A.C. 2004. Desenvolvimento e aplicação de um método para a implementação de sistemas de produção enxuta utilizando os processos de raciocínio da teoria das restrições e o mapeamento de fluxo de valor. Master's dissertation, Universidade de São Paulo. Available at: http: //www.teses.usp.br/teses/disponiveis/18/18140/tde-31072017-

113720/publico/Dissert_Araujo_CesarAC.pdf.

[29] Paris, A. 2013. Sistema Toyota de desenvolvimento de produtos: Uma análise em empresas moveleiras no polo de Bento Gonçalves. Master's dissertation, Universidade de Caxias do Sul - UCS. Available at: https: / / repositorio.ucs.br/xmlui/bitstream/handle/11338/84/Dissertacao\%20Adriano\%20de\%20Paris.pdf? sequence $=3$ \&isAllowed $=y$.

[30] Yin, R. 2017. Case study research and applications: Design and methods, $6^{\text {th }}$ ed. Los Angeles: SAGE Publications.

[31] Stuart, I., McCutcheon, D., Handfield, R., McLachlin, R. \& Samson, D. 2002. Effective case research in operations management: A process perspective. Journal of Operations Management, 20(5), pp. 419-433. doi:10.1016/S0272-6963(02)00022-0

[32] Hayes, R. \& Wheelwright, S. 1984. Restoring our competitive edge - Competing through manufacturing, New York: John Wiley \& Sons Inc..

[33] Womack, J. \& Jones, D. 2003. Lean thinking: Banish waste and create wealth in your corporation, $2^{\text {nd }}$ ed.London: Simon \& Schuster UK Ltd.

[34] Rother, M. \& Shook, J. 1999. Learning to see: Value stream mapping to add value and eliminate MUDA, $1^{\text {st }}$ ed. Cambridge: Lean Enterprise Institute.

[35] Grudowski, P., Wiśniewska, M. \& Leseure, E. 2015. Lean Six Sigma in French and Polish small and mediumsized enterprises - The pilot research results. Key Engineering Materials, 637, pp. 1-6. doi:10.4028/www.scientific.net/KEM.637.1

[36] Shingo, S. 1985. A revolution in manufacturing: The SMED system. Portland: Productivity Press.

[37] Bareji, P., Ismail, N. \& Leman, Z. 2014. Review of lean adoption within small and medium sized enterprises. Advanced Materials Research, 903, pp. 414-418.

[38] Belhadi, A., Touriki, F.E. \& Fezazi, S.E. 2017. Prioritizing the solutions of lean implementation in SMEs to overcome its barriers: An integrated fuzzy AHPTOPSIS approach. Journal of Manufacturing Technology Management, 28(8), pp. 1115-1139.

[39] Chaplin, L., Heap, J. \& O’Rourke, S.T.J. 2016. Could “Lean Lite” be the cost effective solution to applying lean manufacturing in developing economies? International Journal of Productivity and Performance Management, 65, pp. 126-136.

[40] Jiménez, H.F. \& Amaya, C.L. 2014. Lean Six Sigma in small and medium enterprises: A methodological approach [Lean Six Sigma en pequeñas y medianas empresas: Un enfoque metodológico]. Ingeniare, 22, pp. 263-277.

[41] Godinho Filho, M., Ganga, G. \& Gunasekaran, A. 2016. Lean manufacturing in Brazilian small and medium enterprises: Implementation and effect on performance. International Journal of Production Research, 54(24), pp. 1-23.

[42] Jasti, N.V.K. \& Kodali, R. 2016. Lean manufacturing frameworks: Review and a proposed framework. European Journal of Industrial Engineering, 10(5), pp. 547-573. doi: 10.1504/EJIE.2016.078799

[43] Jasti, N.V.K. \& Kodali, R. 2015. Lean production: Literature review and trends. International Journal of Production Research, 53(3), pp. 867-885. doi: 10.1080/00207543.2014.937508

[44] Dora, M. \& Gellynck, X. 2015. House of lean for food processing SMEs. Trends in Food Science \& Technology, 44, pp. 272-281.

[45] Gnanaraj, S.M., Devadasan, S., Murugesh, R. \& Shalij, P. 2010. DOLADMAICS: A model for implementing Lean Six Sigma in contemporary SMEs. International Journal of Services and Operations Management, 7, pp. 440-464.

[46] Khan, Z., Bali, R. \& Wickramasinghe, N. 2008. A business process improvement framework to facilitate superior SME operations. International Journal of Networking and Virtual Organisations, 5, pp. 155-165.

[47] Nguyen, D.M. 2015. A new application model of lean management in small and medium sized enterprises. International Journal of Simulation Modelling, 14, pp. 289-298.

[48] Thomas, A., Barton, R. \& Chuke-Okafor, C. 2009. Applying lean six sigma in a small engineering company - a model for change. Journal of Manufacturing Technology Management, 20, pp. 113-129.

[49] Timans, W., Ahaus, K., Van Solingen, R., Kumar, M. \& Antony, J. 2016. Implementation of continuous improvement based on Lean Six Sigma in small- and medium-sized enterprises. Total Quality Management \& Business Excellence, 27, pp. 309-324.

[50] Vlachos, I. 2015. Applying lean thinking in the food supply chains: A case study. Production Planning \& Control, 26, pp. 1351-1367.

[51] Mostafa, S., Dumrak, J. \& Soltan, H. 2013. A framework for lean manufacturing implementation. Production \& Manufacturing Research: An Open Access Journal, 1, pp. 44-64. doi: http: //dx.doi.org/10.1080/21693277.2013.862159

[52] Belhadi, A., Touriki, F.E. \& El Fezazi, S. 2018. Lean implementation in small and medium-sized enterprises in less developed countries: Some empirical evidences from North Africa, Journal of Small Business Management, 56(S1), pp. 132-153. doi: 10.1108/IJLSS-12-2016-0078 